


\section{La dimensión on-line en la vida social del movimiento 15M. Una aproximación etnográfica}

The on-line dimension in the 15M movement social life. An etnographic approach

DOI: 10.15213/redes.n11.p274

ADRIANA RAZQUIN

\section{ABSTRACT}

This article proposes an analysis of the social and activist uses of virtual communication in the $15 \mathrm{M}$ movement. In general terms, it proposes the rearticulation of off-line and on-line as two areas where activist practices are concentrated, which are not operating in a segregated way and, therefore, can only be understood in an integrated manner. In addition, it presents a resituation of the place they occupy in the general framework of social relationships, symbolic constructions and joint practices of the dispute.

It shows six possibilities of activist uses of the mechanisms that take place on the Internet, explaining which ones were used by the $15 \mathrm{M}$, plus analysis of two more ways that were neither calculated nor explicit: the Internet as a supportive place of ritual chain interactions at a distance and the Internet as a place for emergence subordinate discourses in the assembly space.

KEYWORDS: 15M MOVEMENT, INTERNET, SOCIAL USES, INTERACTION RITUAL CHAINS, SUBORDINATES DISCOURSE. 


\section{RESUMEN ${ }^{1}$}

El presente artículo propone un análisis de los usos sociales y militantes de los dispositivos de comunicación virtual en el movimiento 15M. En términos generales se propone la rearticulación del off-line y el on-line como dos esferas en las que se concretan las prácticas militantes, que no operan de manera segregada y, por tanto, solo pueden comprenderse de manera integrada. Además plantea una resituación del lugar que ocupan en el marco general de relaciones sociales, construcciones simbólicas y articulaciones prácticas de la lucha.

Se exponen seis posibilidades de usos militantes de los dispositivos que operan en Internet, explicitando cuáles fueron las que utilizó el 15M, además del análisis de dos formas no calculadas ni explícitas: Internet como espacio sostenedor de cadenas de rituales de interacción a distancia e Internet como espacio para la emergencia de discursos subalternos en el espacio asambleario.

PALABRAS CLAVE: MOVIMIENTO 15M, INTERNET, USOS SOCIALES, CADENAS DE RITUALES DE INTERACCIÓN, DISCURSOS SUBALTERNOS.

\section{EL LUGAR DE LA COMUNICACIÓN MEDIADA COMPUTACIONALMENTE EN LA ACCión MILITANTE DEL 15M: RESITUACIÓN}

“(..) conviene advertir algunas ficciones. La más importante es aquí la ficción del globalismo, es decir, la ficción de que vivimos en un mundo de hecho globalizado, donde la comunicación transita de modo completamente libre y fluido, liberado de una vez por todas de todo tipo de anclajes socioestructurales; la ficción de que poblamos un mundo de agentes en estado puro, agentes no sujetos, que se prodigan en todas las esferas de la vida. Un mundo en que el individuo puro actúa, por fin, libre de ataduras.Sin embargo, éste no es nuestro mundo”. (DÍAz DE RADA (2010: 48)

\footnotetext{
1. El análisis que se presenta tiene como punto de partida un trabajo socioetnográfico mayor defendido como Tesis Doctoral en mayo de 2014 y que lleva por título Tomar la palabra en el 15M: condiciones sociales de acceso a la participación en la asamblea. Un estudio de caso. Se sitúa temporalmente desde el 15 de mayo de 2011 hasta junio de 2012.

Agradezco a Felipe Aranda Mera las largas conversaciones que mantuvimos en el verano de 2013 mientras preparaba su trabajo Narrativas de autorrepresentación mediadas computacionalmente: el caso del movimiento nacionalsocialista y neonazi chileno; fueron el impulso para escribir este artículo.
} 
Castells explica que los movimientos sociales han dependido a lo largo de la Historia de mecanismos de comunicación específicos más o menos especializados. Comenzando por los rumores, sermones, panfletos y manifiestos divulgados de persona a persona, desde los púlpitos o por la prensa; para llegar, ya en nuestra época, a la comunicación multimodal mediante redes digitales de comunicación horizontal, que es el medio de comunicación más rápido, más autónomo e interactivo, además de reprogramable y autopropagable (CASTELLS, 2012: 32).

En el caso del movimiento $15 \mathrm{M}$, la mediación de las nuevas tecnologías de la información en la articulación del movimiento popular $15 \mathrm{M}$ es evidente. Acogieron desde la gestación de la convocatoria Democracia Real Ya. No somos mercancía en manos de políticos y banqueros, la difusión y acumulación de adhesiones al manifiesto, hasta el primer intento de acampada de la noche del mismo 15 de mayo de 2011 en multitud de plazas (tras la recepción de la aún exigua experiencia en la Puerta del Sol); pasando por la red de interconexiones entre todas las experiencias locales (e internacionales), difusión de denuncias, llamamientos o registros de experiencias y actividades militantes. Sin embargo, conviene visibilizar la tendencia a sobredimensionar el efecto de la herramienta en la comprensión del movimiento que, alimentada por las aproximaciones periodísticas iniciales ${ }^{2}$, ha ido dejando un importante poso en el relato colectivo más extendido.

Rápidamente se tendió a reducir la explicación del origen de la convocatoria, e incluso del movimiento mismo, a la mera constatación del uso de tal o cual herramienta virtual; activando simplificaciones descontextualizadas de un marco más amplio de recursos, estrategias y herramientas militantes - como si indicar alguna de las herramientas utilizadas para activar la demanda colectiva fuera suficiente para explicarlo todo 3 - Se invisivilizaron, de paso, las importantes reuniones presenciales previas a la manifestación que

2. Se puede ver, para ilustrar el caso, la noticia con la que El País inició la cobertura del proceso, "Miles de ciudadanos 'sin casa, sin curro y sin miedo ' exigen 'un futuro digno'" (16/05/2011); ésta otra del mismo medio "El movimiento 15-M, del anonimato al "trending topic'" (17/05/2011); o ésta de El Mundo (17/05/2011), "Internet celebra su día grande y se confirma como herramienta de movilización", dedicada a las celebraciones del Día Mundial de las Telecomunicaciones y la Sociedad de la Información, donde se habla del 15M como una protesta "surgida" de Internet.

3. Algo semejante a reducir la vida políticomilitante del movimiento obrero al efecto de la mera incorporación militante del mimeógrafo; pues aunque éste resultó una herramienta fundamental del accionar político (su posesión definía buena parte de la potencia militante de cada organización o célula), cualquiera se rebelarían ante semejante reducción. 
mantuvieron las diferentes células de Democracia Real Ya con organizaciones de los movimientos sociales locales que sirvieron para la adhesión de colectivos y preparación de la manifestación. Y que fueron, como he mostrado (RAZQUIN, 2015: 69), fundamentales en la movilización de participantes con trayectorias militantes anteriores y posiciones políticas de izquierda; así como para el sostenimiento de la infraestructura militante de la acampada y la incursión del 15M en el espacio de los movimientos sociales críticos.

Desde las primeras semanas, el cuerpo de explicaciones y análisis sobre este proceso ciudadano (donde el tono periodístico desplazó al análisis histórico, antropológico o sociológico) tendió a saturarse rápidamente con significantes ya asignados previamente por los medios internacionales al complejo cuerpo de movilizaciones de las primaveras árabes4: revoluciones 2.0, ciber-movimientos, ciudadanía digital y un largo etcétera. Las diferencias sociopolíticas, incluso aquellas derivadas del enfrentamiento de un movimiento popular a una dictadura militar o a una democracia representativa ${ }^{5}$, se hicieron desaparecer.

Esta tecnomitificación en las explicaciones de la génesis y dinámica del movimiento $15 \mathrm{M}$ se sostuvo sobre dos errores analíticos. El primero implicó, como vengo argumentando, la sobredimensión del uso de los dispositivos que operan en Internet por parte del movimiento (completamente simplicados, además). El segundo, vino cuando finalmente se atendió a las acampadas y se condensó en una aproximación segregada de la vida en el campamento y de la vida en los dispositivos de Internet. Ambos errores dieron como resultado un proceso de generalización de nociones espontaneistas donde se mezclaban aproximaciones parciales que indicaban que aquel proceso se había gestado a partir de una nada cibernética, en contextos completamente adánicos, sin antecedentes y sin organización en la que apoyarse. Una especie de Big Bang creador que desconocía, ocultándolo, todo el entramado de organizaciones, sinergias, encuentros, desencuentros, intentos y antecedentes de otras luchas y organizaciones que sostuvieron,

4. Sobre la complejidad de los procesos de revuelta social desarrollados en multitud de países de tradición árabe, se pueden ver las reconstrucciones de Revilla y Hovanyi (2013) además de la de Castells (2012).

5. Para un análisis macrosociológico completo sobre la diversidad de contextos sociopolíticos (en el marco de las resonancias, complicidades y colaboraciones que se dieron) de los procesos enmarcados en lo que se ha venido a considerar una ola internacional de movilización (Islandia, España, Portugal, Grecia, Estados Unidos, México, Canadá, Colombia, Brasil, Chile, Argelia, Egipto, Túnez y Turquía entre los años 2008 y 2013), puede consultarse el intensivo trabajo de Salinas Salazar (2015). 
apoyaron y/o crearon, tanto la manifestación de Democracia Real Ya como el proceso que arrancaría a partir de ella ocupando las plazas y las calles bajo el nombre de movimiento $15 \mathrm{M}$.

Como evidenció Franck Poupeau (2007: 58-61) para el caso de la Guerra del Agua en Bolivia, este sesgo espontaneista respondía a una concepción miserabilista de los dominados y las dominadas (extensible, en el caso que nos convoca, a los movimientos populares) que llevó a interpretar como espontáneas movilizaciones que, aún cuando se desarrollaron en momentos históricos extraordinarios o contenían ciertos elementos de amateurismo militante, se sostuvieron también sobre redes de relaciones diacrónicas y múltiples esfuerzos coordinados de diversas organizaciones sociales. En el caso del $15 \mathrm{M}$, esta visión sesgada fue además reforzada por buena parte de los y las participantes en el impulso amplificador de la protesta, acompañando la idea de que ninguna organización política o social sustentaba la movilización. Un esfuerzo que se engarzaba, por añadidura, sobre el efecto de adanismo político (MORENO PESTAÑA, 2011A) frecuentemente extendido entre multitud de participantes que iniciaban en el $15 \mathrm{M}$ una trayectoria militante y con el desborde organizativo por la afluencia masiva y constante de nuevos y nuevas participantes, favoreciendo la puesta a cero del contador de la historia política; especialmente la propia.

A medida que se fueron mediatizando las asambleas multitudinarias y las movilizaciones de todo tipo, se fueron reorganizando estas simplificaciones para dar (de algún modo) cobertura a una dinámica militante que lejos de reducirse a la esfera virtual, ocupaba las calles con denuncias y propuestas. Entonces se mantuvieron multitud de análisis que, inexplicablemente, abordaban de manera segregada y dispersa la vida en el campamento, en las calles, en las plazas, de la vida en Internet. Comprendiendo a las articulaciones prácticas virtuales, a las comunicaciones mediadas computacionalmente (DÍAZ DE RADA, 2008 y 2010), como si no fuesen lo que son: prácticas sociales; y como si los y las protagonistas fuesen otra cosa distinta a agentes sociales actuantes en el marco de un contexto social ${ }^{6}$. Algo que resultó, además, de lo

6. En fin, olvidando, por extraño que resulte, que Internet es uno de los medios por los que la gente se comunica pero que, como no podía ser de otro modo, ni genera el contenido ni la voluntad de encontrarse, comunicarse, compartir o debatir. Mucho menos de organizarse y sostener una movilización. Cosa bien distinta es que, como sucede (y sucedió), la mediación de Internet haga posibles experiencias comunicativas deslocalizadas e inmediatas, estrategias de autorrepresentación y juegos performáticos, además de usos creativos del lenguaje, posibilidades amplias de establecer relaciones y conversaciones ágiles, abrir ciertas fisuras por las que acceder más rápidamente a la interpelación 
más equivocado al desconocer, como han señalado diversos autores frente a la tecnomitificación del levantamiento zapatista (TRERÉ Y BARRANQUERO, 2013: 34-36) ${ }^{7}$ que inauguró la exploración militante del Internet 1.0 a finales del siglo pasado, que la fortaleza de estas movilizaciones residía, precisamente, en su total engarce en dinámicas de relaciones sociales y comunicativas cotidianas presenciales, así como en el uso de los medios de comunicación más clásicos (radio, televisión y prensa) en un marco de relaciones políticosociales diacrónico.

En ese sentido, Romanos (2015), en armonía con el trabajo de Lawrence $(2013)^{8}$, ha mostrado que la importación de la cultura organizativa del $15 \mathrm{M}$ en Occupy Wall Street se dio de la mano de la significativa participación de migrantes de origen español y de estadounidenses que habían participado anteriormente en la acampada de la Puerta del Sol. Este proceso de incorporación de la cultura militante del $15 \mathrm{M}$ se produjo en el marco de organizaciones previas que sostuvieron o fueron antecedente de los llamamientos de Occupy Wall Street - New Yorkers Against Budget Cuts o Democracia Real Ya-NYC, por ejemplo (LAWRENCE 2013: 59) - y se concretó en dos iniciativas llevadas a cabo por emigrados y emigradas de España, ambas con la intención de mantener la acampada abierta a la participación al estilo del 15M: creación de un puesto de recepción e información, el open forum (versión neoyorquina de las charlas-debate organizadas en las plazas del $15 \mathrm{M}$ ) y la utilización de manuales creados por el $15 \mathrm{M}$. En este último caso, merece la pena detenerse en el análisis de la recepción que hace Romanos (2015) del documento Cómo Cocinar una Revolución Noviolenta, ya que, según explica, si bien había sido distribuido en Internet por parte de sus creadores, la World

directa de representantes públicos, así como trastocar (nunca derribar) las relaciones de dependencia con respecto a los grandes organismos públicos y privados de comunicación. También permite (y permitió, sin duda, al 15M) la internacionalización de la protesta y las adhesiones a una velocidad sin parangón a lo largo de la historia política del país.

7. Se puede ver, en la misma dirección, el análisis de Galindo Cáceres (1997: 326-344) estructurada sobre lo que llamó dimensión social y dimensión virtual del EzLN.

8. Una reconstrucción sobre el origen de Occupy Wall Street crítica con la propuesta analítica de Hardt y Negri (2012) - un análisis del ciclo de movilización iniciado en 2011 sobre la base de unas características comunes: movimiento sedentario, multitudes organizadas sin líderes, toma de decisiones en el marco de la horizontalidad y unas estrategias del común contra las formas dominantes de subjetividad producidas en el contexto de la actual crisis social y política (indebted, mediatized, securitized, represented) - . Lawrence considera que en la misma están invisibilizadas las trayectorias sociopolíticas, contingencias y migraciones que fueron el corazón de la emergencia del movimiento neoyorquino. 
Extention Team de Acampada Sol, "sin embargo, a juzgar por los testimonios recogidos en las entrevistas, su recepción en Estados Unidos se apoyó en los contactos interpersonales creados por los emigrantes españoles y otros activistas transnacionales: estadounidenses que habían participado en el movimiento en España y que luego participaron en el surgimiento y desarrollo de ows. Según activistas y observadores locales, estos materiales fueron relevantes en Zuccotti Park, sobre todo en relación con el funcionamiento de la asamblea general y la organización del espacio en la acampada".

Para el caso del origen de las movilizaciones de la primavera de Egipto y el colectivo impulsor de las protestas, el Movimiento 6 de Abril, Garrido, et al. (2013) explican cómo venían organizándose en la plataforma Facebook desde abril de 2008 para apoyar las huelgas sindicales obreras en Mahalla, una ciudad industrial. En este caso, adaptaron la utilización de esta red virtual para crear espacios y formas alternativas de comunicación con las y los jóvenes en general, con otras organizaciones sociales y políticas que ya existían y con los medios de comunicación.

Como indican estas investigaciones y ya apuntó Charles Tilly (2005: 12-13) en su trabajo sobre las movilizaciones de enero de 2001 en Manila, es necesario atender a la innovación de la llamada a la movilización (en el caso manilense fue por mensajes de texto a teléfonos móviles), pero no en sí misma, sino en su papel de herramienta. $\mathrm{Y}$ desde esa perspectiva situada, entrar, ahí sí, a explorar en qué modo y medida la herramienta jugó un papel en la definición del proceso. Pues, en el marco de la multiplicidad de concreciones de los usos militantes y políticos de las nuevas tecnologías de comunicación, conviene recordar que la esfera virtual de la vida militante, aun preservando dinámicas y lógicas particulares, no acontece desligada del resto de elementos que componen la vida social de los movimientos; no opera desarraigada del marco de condiciones de posibilidad que median en cualquier proceso.

En esta dirección, este artículo está concentrado en describir y analizar las concreciones empíricas, en la máxima variabilidad fenomenológica, en las que la comunicación mediada computacionalmente aconteció en el marco más general de la vida social del movimiento $15 \mathrm{M}$. Esto es, en explicar los usos sociales (BOURDIEU, 1999 [1988]: 18) de los medios tecnológicos que operan en Internet sin perder de vista el marco más general de prácticas militantes (o de manera más amplia: prácticas sociales) en las que se inscribieron. Como plantea Couldry (2004: 128) en su propuesta de refocalización de los análisis de los medios de comunicación, la idea es desplazar el foco hacia interrogaciones basadas en el papel de las prácticas relacionadas con los medios de comunicación (en el caso que nos atañe, con los dispositivos virtuales de 
comunicación) en el ordenamiento más general de la vida social (en nuestro caso, de la vida social del movimiento $15 \mathrm{M}$ ). Solo de este modo podremos aprehender el papel que jugaron estos dispositivos de comunicación virtual en el marco general de las prácticas militantes, así como en la vida emocional y simbólica del proceso $15 \mathrm{M}$.

Esta perspectiva me ha permitido resituar el lugar que ocuparon como mediadores en la construcción de los procesos enmarcadores (sNOw ET AL.,1986); o dicho de otro modo, del grado de generalidad en la definición de la causa (BOLtANSKI, 1990) que marcó los límites interiores y exteriores de la identidad colectiva. Revelándose que los procesos de desarrollo y concreción del sujeto político del $15 \mathrm{M}$, así como de los fines últimos de la lucha (y las estrategias militantes para lograrlos), lejos de armonizarse espontáneamente en los dispositivos virtuales, fueron el producto de una larga y sostenida lucha por el significado de la lucha (MATHIEU, 2004). En la contienda participaron multitud de agentes ${ }^{9} \mathrm{y}$ tuvo como escenario principal de concreción y desarrollo las asambleas, aunque inundara (en cantidad) las redes sociales virtuales (que se alimentaron en numerosas de ocasiones por las posiciones expresadas en los medios de comunicación tradicionales: ensayos, cartas de opinión, entrevistas, etc. $)^{10}$. Porque, tal y como comencé planteando, es indiscutible que

9. Debe comprenderse la «lucha» en el marco de la teoría de la acción social de Pierre Bourdieu y, esto es importante, lejos de un encuadre en un marco de acción racional. Debe ser entendida como producto de la illusio. Esto es, de la inversión en el campo o en un espacio del mismo (campo político, espacio de los movimientos sociales), habitualmente prerreflexiva (disposiciones, habitus y sentido práctico), que es impulsada por la adhesión a la lógica específica del campo (creencia en el juego y en lo que se juega en él: la doxa), que está adscrita a la posición social que se ocupa en el campo en cuestión. Un campo que, por otro lado, no es otra cosa que un espacio en lucha por las permanencias y los cambios y por el establecimiento de los principios de visión y de división que lo ordenen. Por otro lado, como todo proceso disputado, implica cooperaciones, negociaciones y acuerdos.

10. Si nos centramos en las discusiones o expresión de opiniones en las redes sociales virtuales, encontraremos que habitualmente tienen como desencadenante una nota de prensa, una entrevista televisiva o suceso registrado y filmado. Salvo en este último caso (donde con frecuencia el contenido procede de medios activistas), la dinámica comunicacional en los espacios militantes virtuales (cuentas de Twitter y Facebook principalmente), suele tener su origen en la recepción de contenido producido y/o difundido en los medios de comunicación masivos - en mucho menor porcentaje de medios alternativos - . Algo que parece lógico si se atiende a la capacidad y voracidad con la que los medios de comunicación de masas producen y amplifican contenido informativo y de opinión. Por otro lado, siguiendo a Candón Mena (2012: 686) es importante reparar en que en ese proceso los mensajes mediáticos son reinterpretados: "la realidad es filtrada por los medios convencionales, pero del mismo 
los dispositivos de Internet fueron fundamentales para la interconexión entre todos los entes del movimiento $15 \mathrm{M}$ y, en ese sentido, clave en la importación de ideas, relatos o sucesos de otras acampadas, procesos o movilizaciones internacionales; pero el mismo día que la convocatoria saltó de las redes sociales virtuales a los primeros encuentros locales con asociaciones y colectivos que cada célula de DRY desarrolló en sus ciudades o pueblos para organizar la manifestación del 15 de mayo de 2011, la vida on-line del movimiento pasó a ser, en la generalidad de las dinámicas y los efectos, subsidiaria de la vida off-line. Además, conviene tener presente que el propósito del primer manifiesto, elaborado por un grupo de personas organizadas de manera deslocalizada gracias a los dispositivos virtuales ${ }^{11}$, fue siempre llamar a la movilización en las calles de todo el territorio nacional. De igual modo había sucedido con Estado del Malestar, que saltó del portal Facebook a la Puerta del Sol el 11 de febrero de 2011 (ANTOLÍn, 2014); configurándose como la antesala del importante ciclo de movilización que se abriría en apenas tres meses más.

Sobre estas premisas, que se incorporan a un planteamiento analítico que reinserta la dimensión on-line de la protesta en el marco más general de la vida militante, abordaré el análisis de los usos sociales y militantes de los dispositivos que operan en Internet por parte del movimiento $15 \mathrm{M}$.

\section{USOS MILITANTES DE LOS DISPOSITIVOS ON-LINE}

Planteados algunos presupuestos de partida, resultará interesante señalar que los usos militantes de Internet son diversos y que el $15 \mathrm{M}$ no articuló todos. Podríamos agruparlos en seis categorías que se aglutinan, siguiendo a Candón Mena (2011: 268-270), entre la acción disruptiva no destructiva (daño temporal y reversible), la acción convencional, donde se utilizan los cauces establecidos para la participación: se enmarca en el uso permitido

\footnotetext{
modo los mensajes mediáticos son filtrados por las redes sociales en Internet. Los comentarios en los foros y páginas de información on-line, la redistribución de noticias a través de listas y correos electrónicos, la difusión de interpretaciones y opiniones en la blogosfera, etc., pueden alterar el marco interpretativo de la realidad difundida por los medios".

11. No debe olvidarse, por otro lado, que buena parte de los antecedentes de la convocatoria (reuniones, experiencias de movilización previas, etc.) se enraízan en la vida política madrileña. Se puede ver, al respecto, la reconstrucción de lo que he denominado prehistoria del movimiento 15M (RAzQUIN, 2015), con tres bloques alimentadores \#Nolesvotes, Coordinadora Ciudadana y Juventud Sin Futuro; de los que únicamente \#Nolesvotes mantiene su dinámica de prácticas en la esfera virtual.
}

REDES.COM N $\mathbf{N}^{\circ} 11 \mid 283$ 
aun cuando se trate de bloquear un sistema; y la acción institucional: se utilizan los canales y las formas establecidas en la recogida de firmas o envío masivo de mensajes.

(a.) Encuentro: las relaciones sociales virtuales previas que dan lugar a una protorganización. Podríamos decir que este uso tiene un carácter relativamente fortuito (no por ello involuntario) y es una extensión de las relaciones sociales ordinarias que se desarrollan en las redes sociales virtuales. Esta es una de las características más significativas, especialmente desde el punto de vista de la constitución de las organizaciones (germen e ingreso de nuevos y nuevas participantes), en los procesos de la llamada nueva ola de movilización internacional. Sin embargo, huelga decir, que esta vía no fue exclusiva y que se solapó con múltiples relaciones con organizaciones estructuradas en la interacción cara a cara. Una vez se levantaron las acampadas, los grupos de trabajo y las nuevas asambleas se constituyeron principalmente en la red de interacciones presenciales, tanto en las asambleas como en conversaciones informales y espacios físicos de encuentro, trabajo político, sostenimiento de la vida cotidiana y ocio del campamento (de las comisiones de trabajo ya existentes a la cocina, pasando por biblioteca o la cama turca).

(b.) Difusión de información, análisis políticos, denuncias, propaganda, llamadas a la movilización o recogida de adhesiones a campañas (firmas, selfies con el eslogan de la campaña, envío de mensajes tipo, etc.); corresponde a la "infoguerra de base" descrita por Wray (1999 en Candón Mena, 2011: 271-272). Incluyo en este grupo también a la producción audiovisual videoactivista que es difundida esencialmente por Internet, cuyo protagonismo en las campañas militantes es realmente significativo. Siguiendo a Askanius (2013: 5-7) en su análisis sobre la producción videoactivista ${ }^{12}$ alojada en YouTube, se pueden establecer cuatro agrupaciones: a) movilization videos: piezas audiovisuales que llaman explícitamente a la acción política, a sumarse a las protestas o a difundir llamamientos; b) witness videos, que documentan condiciones

12. Este tipo de producción audiovisual se caracteriza, siguiendo a Mateos y Rajas (2014: 22-30; 41, 46), por vincularse con proyectos y posiciones políticas con voluntad transformadora progresista de la realidad social (independientemente de que tenga éxito), así como por una voluntad militante: colectiva aún cuando no haya integración orgánica. También por desarrollarse fuera de los esquemas de la producción industrial hegemónica y por movilizar una información o argumentación alternativa a la visión dominante en los medios de comunicación masivos. 
injustas concretas, violaciones de derechos humanos, brutalidad policial, etc. c) documentation videos, que de manera directa documentan manifestaciones, charlas, intervenciones, acciones directas etc.; d) archived radical video de YouTube, que acoge multitud de cintas históricas con contenido y posición política de izquierda radical y e) political mash-ups, que agrupa a una amalgama de montajes, mezclas, recortes y collages audiovisuales construidos para sostener un argumento político.

Por otro lado, resulta significativo que, en el desarrollo de este uso, Internet opera como mediador entre las prácticas militantes y las y los simpatizantes. Explicaré más adelante que esta mediación suele operar inmersa en la activación de rituales de interacción a distancia, haciendo circular mucha energía emocional entre personas deslocalizadas mediante dinámicas de metonimia con experiencias prácticas anteriores en las acampadas y asambleas con las que existe un fuerte engarce emocional.

No debe perderse de vista que la difusión por esta vía no hace desechar otras formas más clásicas de difusión que siguen siendo imprescindibles para mantener la diversidad en el sujeto político llamado a movilizarse (buzoneo, cartelería en las calles, llamadas telefónicas y mensajes de texto o reparto de panfletos y divulgación en los entornos sociales próximos: vecindario, familia, comercios locales, etc.; así como en la acampada). Tampoco que, desde el punto de vista del papel que juega en el plano militante, existe una clara continuidad (superando, claro está, la innovación de la herramienta que modela el canal y permite innovación en el lenguaje) con otros formatos militantes anteriores en los que se condensa la lucha por la significación, así como con otras formas, también audiovisuales (o no) de difusión de idearios, análisis o propaganda (obras de teatro, murales, poemarios, cuentos o cine arte).

(c.) Gestión de la organización: tanto a nivel interno como con otros colectivos, con listas de correos electrónicos y grupos en redes sociales virtuales, formando parte del "activismo informatizado" siguiendo la categorización de Wray (1999 EN CANDóN MENA, 2011: 271).

(d.) Ciberacción directa, que implica el sabotaje sostenido mediante una acción colectiva coordinada dentro de la esfera cibernética; que transita entre la "desobediencia civil electrónica" y el "hacktivismo" (Ob. cit.: 272276). Esto es, el sabotaje a páginas web o perfiles de empresas, partidos políticos u organismos estatales: un ataque a la esfera de la autorrepresentación virtual como medida de presión y demostración de fuerza (suele ser nece- 
sario que participen muchas personas al mismo tiempo para que funcione). Diferencio la ciberacción directa, que sería una especie de acción directa en el plano virtual, de otros ejercicios militantes en Internet, como son las adhesiones a campañas, por ejemplo, porque el uso de la tecnología virtual en el caso de los segundos es meramente instrumental: no hay una transformación sustancial de la dinámica, simplemente un desplazamiento para aprovechar las ventajas de la amplificación de la difusión por Internet ${ }^{13}$. En estos casos, la finalidad es la difusión y el espacio donde se articula políticamente es otro diferente del virtual: el Parlamento, la Audiencia Provincial, etc. Excluyo estas situaciones de la categoría ciberacción directa porque me interesa resaltar la innovación y la caracterización de las nuevas formas de presión política que ha internacionalizado Anonymous. Pues resulta primordial reparar en que la apuesta de acción colectiva de los anons reside en el sabotaje de la esfera de autorrepresentación virtual de entidades gubernamentales, grandes empresas o representantes públicos. También de los soportes virtuales de atención al público, pero generalmente, aún cuando dificulten o imposibiliten tareas de gestión, el efecto fundamental se sitúa en el plano del deterioro (mediante la mofa o burla) de la imagen pública y la vulnerabilidad que manifiesta. Es pues ésta una nueva vía de acción colectiva enmarcada completamente en la esfera de las comunicaciones virtuales: es en el espacio on-line donde se coordinan de manera deslocalizada multitud de participantes para el desarrollo de una acción colectiva de sabotaje al perfil público de una entidad, o agente en cuestión, como medio de demostración de fuerza, de multitudes que apoyan la denuncia, unas exigencias, etc. De manera frecuente, será tras la recepción y amplificación de la noticia

13. Lo que no supone desconocer el potencial de la comunicación viral a la hora de forzar a los medios de comunicación masivos a tratar determinados temas o, como en el caso de la irrupción del 15M en la vida política española, movilizar una interpelación de las y los periodistas a quienes ostentan cargos de representación política (desde cargos del Gobierno a secretarios generales o portavoces de partidos políticos, sindicatos, patronal) por el propio proceso de movilización popular. Así, en el mismo momento en que los y las periodistas - que con su actividad cotidiana operan como gatekeepers del campo político (BOURDIEU, 2000: 4) - comenzaron a pedir valoraciones sobre el $15 \mathrm{M}$ a las y los representantes políticos, hacían posible la entrada de este movimiento al centro del campo político.

Por otro lado, la mediación de las comunicaciones on-line en la presión ciudadana a los medios de comunicación para que den cobertura a sucesos, movilizaciones o escándalos políticos que están "quemando en la Red" es uno de los efectos más visibles de la transformación que ha supuesto, en mitad de la sociedad de la información, la masificación e intensificación del consumo de dispositivos de comunicación virtual interpersonal. 
por los medios de comunicación masivos (al quedar en evidencia pública el sabotaje) cuando el hackeo culmine su efecto en los centros de poder político y económico.

Esta nueva forma de acción directa en el espacio virtual ocupa un lugar a medio camino entre la cyberwar y la social netwar (en esta última quedarían incluidos todos los demás usos que he descrito), acuñadas por Ronfeldt y Arquilla (1993 Y 1998, EN TRERÉ y BARRAQUERO, 2013: 35). Pues mientras la intención es hackear, al mismo tiempo, no pertenecería a la cyberwar por estar ésta referida claramente al hacking realizado por los ejércitos en un contexto de guerra. Al mismo tiempo, comparte elementos de la definición y contexto de aplicación de la social netwar, construida prácticamente en el análisis de las acciones zapatistas tras el levantamiento de San Cristóbal de las Casas, en tanto que "[...] nueva forma de protesta desarrollada por diferentes grupos horizontales que adoptan múltiples formas de resistencia, entre las cuales Internet juega un importante papel a nivel organizacional y comunicativo" (IBÍD.). Todo parece indicar que la ciberacción directa supone un salto cualitativo en la social netwar, pues supera la mera organización o difusión mediada computacionalmente, que se desarrolla básicamente en los marcos ordinarios de los usos de Internet, por la acción directa en y para el mundo virtual, que se desarrolla subvirtiendo el desarrollo ordinario del intercambio de información; bien para saturar mediante peticiones masivas y simultáneas a un servidor que termina bloqueándose o bien para trampear los derechos de propiedad y gestión colocando imágenes o redireccionando las solicitudes de visita de la página o perfil público en cuestión hacia un mensaje.

Esta nueva forma de acción directa en el espacio virtual ocupa un lugar a medio camino entre la cyberwary la social netwar (en esta última quedarían incluidos todos los demás usos que he descrito), acuñadas por Ronfeldt y Arquilla (citado en treRéy BARRAQUeRo, 2013: 35). Pues mientras la intención es hackear, al mismo tiempo, no pertenecería a la cyberwar, por estar ésta referida claramente al haking realizado por los ejércitos en un contexto de guerra. Al mismo tiempo, comparte elementos de la definición y contexto de aplicación de la segunda, la social netwar, construida prácticamente en el análisis de las acciones zapatistas tras el levantamiento de San Cristóbal de las Casas, en tanto que “(...) nueva forma de protesta desarrollada por diferentes grupos horizontales que adoptan múltiples formas de resistencia, entre las cuales Internet juega un importante papel a nivel organizacional y comunicativo" (IBÍD.). Todo parece indicar que la ciberacción directa supone un salto cualitativo en la social netwar, pues supera la mera organización o difusión 
mediada computacionalmente, que se desarrolla básicamente en los marcos ordinarios de los usos de Internet, por la acción directa en y para el mundo virtual, que se desarrolla subvirtiendo el desarrollo ordinario del intercambio de información; bien para saturar mediante peticiones masivas y simultáneas a un servidor que termina bloqueándose o bien para trampear los derechos de propiedad y gestión colocando imágenes o redireccionando las solicitudes de visita de la página o perfil público en cuestión hacia un mensaje.

(e.) Deliberación, gracias a dispositivos virtuales de gestión y moderación de conversaciones grupales que permiten la conectividad deslocalizada de participantes (si bien siguiendo la categorización de Wray, formaría también parte del "activismo informatizado", al igual que la que se presentará a continuación; considero que resulta analíticamente esclarecedor separarlas, pues suponen actividades militantes significativamente diferentes). Descarto de esta categoría las conversaciones en grupos virtuales o los debates en hilos de conversación de redes como Facebook o Twitter, pues no otorgan garantías mínimas para la deliberación, no tienen un mínimo grado de institucionalización respecto del proceso de discusión y, lo más importante, quienes participan no lo hacen con la intención de ponerse de acuerdo con otros y otras en alguna cuestión (salvo en el primer caso, el encuentro): son espacios donde se expresan opiniones. Es decir, son para el espacio virtual lo que para el espacio asambleario con co-presencia corporal es el "micro abierto".

(f.) La toma de decisiones, donde se incluyen desde dispositivos de voto de propuestas que permiten las redes sociales (utilizado para cuestiones internas en grupos pequeños) hasta otros, con un grado mayor de institucionalización y complejidad, como los utilizados por el Partido X y para las primarias en Podemos.

De todas las posibilidades de usos militantes de Internet descritas hasta el momento, las prácticas del movimiento $15 \mathrm{M}$ se restringieron únicamente a las tres primeras. La ciberacción directa caracterizó las campañas de Anonymous, que irrumpía el 21 de diciembre de 2010 con más de 5.000 personas coordinadas para tumbar las webs de los partidos que apoyaban la "Ley Sinde" (consiguiendo importantísimos corrimientos y cambios de posiciones en las votaciones en el Congreso).

Respecto al uso de los medios virtuales para la deliberación y la toma de decisiones, fue en Democracia Real Ya, en su paso a colectivo, donde se implementó esta forma de ciberasambleas. Pero, por su parte, el 15M se 
estructuró eminentemente sobre asambleas (y grupos de trabajo) presenciales y locales donde planificar, deliberar y tomar decisiones, y recurrió estrictamente a la acción colectiva callejera; desde la primera noche, cuando se comenzaron a levantar los campamentos.

Más allá de las seis categorías presentadas que agrupan usos explícitos de Internet, me extenderé presentando otros dos usos más de estas herramientas en el 15M. Unos usos no explícitos, no siempre medidos y, la mayoría de las veces, solo perceptibles a condición, como vengo defendiendo, de una reinserción de las relaciones sociales virtuales en el marco general de prácticas sociales del (y en el) movimiento.

\section{INTERNET COMO SOSTENEDOR DE CADENAS DE RITUALES DE INTERACCIÓN}

Un ritual de interacción (RI), explica Collins, es un "modelo de situaciones de interacción" que varía en función de dos elementos que lo estructuran: un foco de atención común y una consonancia afectiva que nace entre las personas participantes asociada a una coordinación rítmica (COLLINS, 2009: 1-2, 111).

El mecanismo central de la Teoría de Rituales de Interacción (la tri) funciona de la siguiente manera: hay situaciones sociales que conjugan tanto un alto grado de foco de atención compartido (que supone, por tanto, un nivel elevado de intersubjetividad) como un alto grado de consonancia emocional, que sucede gracias a la sincronización corporal, fruto de la estimulación y/o excitación del sistema nervioso de quienes participan. Cuando esto sucede, se logran producir sentimientos de membresía grupal (que están unidos a símbolos cognitivos) en forma de energía emocional (EE) que sienten quienes participan(ов. сіт.: 65). Esta energía emocional "les instila sentimientos de seguridad en sí mismos, entusiasmo y deseo de que sus actos sigan la senda de lo que juzgan moralmente correcto" (IBíD.).

La efervescencia colectiva que producen las situaciones de interacción, muy focalizadas y cargadas de mucha energía emocional, se inscribe ("prefunde" dirá Collins) en los cuerpos de quienes participan en ella y así, llevarán consigo esa emoción generada en grupo. De este modo, la agencia, que describe como la "energía que anima los cuerpos humanos y sus emociones y como la intensidad y el foco de la conciencia humana" emerge de las interacciones y de las situaciones cara a cara o puede precipitar cadenas de situaciones (ов. сіт.: 3, 20-21). Así, las emociones situacionales inmediatas con "su escondida resonancia de membresía grupal" van perviviendo de una situación a otra en forma de energía emocional (EE) y, con el tiempo, van 
forjando cadenas de rituales de interacción (ов. сіт.: 3). El autor propone el modelo de Cadenas de Rituales de Interacción como aquello que:

impulsa a los individuos de una situación a otra guiados por pautas análogas a las de un mercado, en función de las cuales el acervo de recursos sociales de cada participante en un encuentro, su EE y sus símbolos de membresía (o capital cultural), acumulados en RI anteriores se combinan con los demás. El modo o medida en que esos elementos encajen es la clave del tipo de RI que se producirá cuando esas personas se aglutinen (ов. сіт.: 4).

Un ritual tiene principalmente cuatro condiciones o ingredientes iniciales, que se retroalimentan, y de los cuales el tercero y cuarto (foco común y experiencia emocional compartida) son los fundamentales. Opera del siguiente modo: primero, dos o más personas se encuentran físicamente en un mismo lugar, así que, esté o no su presencia corporal en un primer plano de su atención, esa presencia corporal les afecta de manera recíproca. Segundo, existen barreras excluyentes que sostienen la distinción entre quiénes participan y quiénes $\mathrm{no}^{14}$. Tercero, todas las personas que participan están focalizadas sobre el mismo objeto y al hablar de ello toman conciencia conjunta de que el foco es común. Y cuarto, la experiencia emocional es compartida; esto es, el estado anímico es el mismo. Así, conforme los y las participantes se centran cada vez más en su experiencia compartida y toman conciencia, precisamente, de que es compartida,

(...) experimentan su emoción común con tal intensidad que domina su conciencia. A medida que el ritual procede, crece el entusiasmo de los componentes de un público ${ }^{15}$ que no cesa de aclamar, los participantes en un servicio religioso asumen una actitud más respetuosa y solemne y los asistentes a un funeral sienten cómo su pena se agranda (ов. сіт.: 72-73).

\footnotetext{
14. Cualquier ritual tiene un doble efecto estratificador. De un lado diferencia entre incluidos y excluidos de él. De otro, entre quienes lideran el ritual y quienes lo siguen (Ob. cit.: 64).

15. En las asambleas del 15M no había público en estricto rigor, pero sí la moderación era quien dinamizaba el acontecer asambleario, el desarrollo del ritual. Y, a medida que avanzó el proceso (cuarta semana), las y los militantes a tiempo completo desde los grupos de trabajo.
} 
Si los elementos que componen el ritual se combinan con acierto (como decía, fundamentalmente esto resulta cuando existe un foco de atención coincidente y una experiencia emocional compartida), se logran sentimientos de membresía grupal (solidaridad grupal) y energía emocional en el plano individual: sensación de confianza, alegría, fuerza, entusiasmo e iniciativa para la acción. También se activan símbolos que representan al grupo: que pueden ser lemas ("No nos representan"), íconos (las plazas, los campamentos, los toldos) o gestos (lenguaje de signos aplicados a la asamblea) que quienes participan del ritual sienten asociados a sí mismos como colectividad.

Pues bien, aplicando esta propuesta analítica al proceso del ${ }_{15} \mathrm{M}^{16}$ en el tiempo de las acampadas, se hace evidente que cada tarde-noche, cuando comenzaba la asamblea, circulaba gran cantidad de energía emocional. El foco de atención era compartido con mucha intensidad (la asamblea-acampada como vía paralela de participación política directa) y la consonancia emocional era altísima, así que se generaban día a día sentimientos de membresía grupal muy altos que tendían a opacar las divergencias que existían respecto a los fines últimos y medios para la lucha. En este momento del proceso, el ritual alimentó constantemente cadenas de interacción: las y los participantes acuden a la plaza y tras participar de las asambleas, con el sonido de la multitud y la co-presencia corporal alimentando la energía emocional (ов. сіт.: 81-84), comer algo en la cocina o conversar en alguna comisión, salen del espacio transportando en su cuerpo esa efervescencia colectiva: “(...) quienes han participado en RI consumados desarrollan un gusto por esa misma clase de solidaridad ritual y están motivados para repetirlos" (ов. сіт.: 203). Al mismo tiempo, la presencia personal en la multitud, elevada colectivamente a una enardecida emoción compartida, confiere el ímpetu preciso para reconfigurar la propia identidad (ов. сіт.: 88) surgiendo, de este modo, significantes colectivos bajo los que identificarse e identificar al proceso político.

16. Quisiera poner de manifiesto que si bien rescato la teorización general de Collins por su gran riqueza a la hora de abordar desde ella la movilización popular del 15M, pues permite explicar microsociológicamente qué sucedía en las plazas y en Internet, no comparto la forma en la que Collins aborda la disposición a la acción de los individuos: las teorías de la acción racional —incluso el mismo el autor reconoce las "anomalías" que de estas teorías se derivan, puesto que las personas no calculamos bien las opciones de las que hipotéticamente gozamos en una microsituación (2009: 197)—. Como alternativa, adscribo la propuesta de Bourdieu del "sentido práctico", que implica el encuentro entre un habitus (y todo el entramado de disposiciones dispares sobre las que logra articular una respuesta más o menos armonizada) y un campo social: el encuentro entre la historia objetivada y la historia incorporada (GUTIÉRREZ, 2002: 73-74). 
Ahora bien, ¿qué papel jugaron los dispositivos de comunicación virtual en el marco de las Cadenas de Rituales de Interacción que se encabalgaban teniendo como epicentro el ritual de interacción en la acampada-asamblea?

La teorización de Collins comprende la posibilidad de actividad humana en solitario como algo poco frecuente - se prefieren rituales con co-presencia corporal, por eso la gente sigue yendo a los estadios de fútbol o a los buenos mítines (ов. сіт.: 84) - y donde, en cualquier caso, no debe perderse de vista que en ese "actuar en solitario", las mentes y los cuerpos están ya cargados con los efectos de encuentros situados anteriores. Por lo que las acciones solitarias también son sociales, en tanto que provienen y están orientadas a la comunicación con otras personas; “(...) lo que las sitúa es su ubicación en una CRI particular" (ОВ. СIт.: 20-21). Al mismo tiempo, las interacciones a distancia suelen transmitir una sensación de participación defectiva (ов. сіт.: 80) у es la forma en la que muchos y muchas tratan de mantener el vínculo militante con el proceso cuando, por diversas razones, no pueden participar en acciones o se ven en la obligación de interrumpir su participación en el proceso político-organizativo. Lo hacen posteando, comentando y celebrando en la esfera on-line lo que apenas unas horas antes han sostenido otros y otras en diversas partes. Con más intensidad, cuanto más sentimiento de proximidad y de colectividad se tenga con el grupo humano en cuestión. Es importante señalar que no tiene que ver con una proximidad geográfica o contextual inmediata, sino con los significantes que constituyen los sentimientos de membresía. Así, se puede asumir como más cerca y hermana la lucha de la población egipcia contra la dictadura de Mubarak, o la siria contra la de Al-Asad, y rechazar la manifestación pública de apoyo a una lucha sindical que se desarrolla en la misma ciudad si ésta está liderada por ccoo y UGT; o la presencia simultánea en la plaza de la acampada de una concentración LGBT por la despatologización de la transexualidad, por estar apoyada por IU, PSOE, CCOO y UGT (por poner dos ejemplos reales que se sucedieron a las proyecciones in streaming de las movilizaciones en la plaza Tahrir en la acampada-asamblea estudiada). Nada paradójico si se atiende a que lo que sucede es que los significantes de proximidad geográfica quedan detonados en un universo supranacional (somos el 99\% que dirán desde ows) que ya habría explosionado, al albur de la universalización de la conectividad a Internet, el movimiento antiglobalización, con el Zapatismo Intergaláctico como ejemplo paradigmático ${ }^{17}$.

17. Se puede ver un movimiento similar (ciertamente en un estado muy anterior a las telecomunicaciones mundiales y en el marco del programa emancipatorio del marxismo y el anarquismo) en la misma 
Los dispositivos que operan en Internet pueden mantener la energía emocional y la solidaridad grupal porque pueden re-evocar símbolos - donde quedan almacenadas las emociones inmediatas en forma de emociones duraderas-(ов. сіт.: 114). Pero conviene tener en cuenta un par de cuestiones a este respecto. Primero, las interacciones rituales a gran escala operan con símbolos cargados tiempo atrás, lo que significa que han tenido que ser cargados en el decurso de una interacción previa de una CRI (que implique co-presencia corporal). Y segundo, si bien la comunicación a distancia infunde la sensación de pertenecer a algo grande, será efectiva únicamente si hay, como mínimo, un contacto intermitente con otros y otras participantes que comparten esos símbolos (ов. сіт.: 90). Por esa razón, poco a poco, a medida que se fue enfriando la adhesión emocional al ${ }_{15} \mathrm{M}^{18}$, el ritual de interacción en la asamblea comenzó a ser, una y otra vez, primero forzado y más adelante fallido. Este proceso fue simultáneo a la protocolización del espacio asambleario y a la predominancia de los grupos de trabajo en el proceso, que consolidan el paso (se da al compás del proceso de ritual fallido que describo) de movimiento popular a movimiento social y que se caracteriza por la formalización del ritual de interacción.

Sin embargo, la circulación de energía emocional y la adhesión al proceso pervivió en Internet mucho más tiempo, y comenzó a desmoronarse mucho más tarde. ¿Por qué? Porque la mayoría de quienes revivían los sentimientos de plenitud, euforia y membresía grupal en el medio virtual lo hacían respecto de experiencias aposentadas exclusivamente sobre prácticas relativas a las tres primeras semanas de acampada. Esto es, porque no habían tenido la experiencia (común a las y los militantes a tiempo completo) de participar en rituales forzados - el foco de atención no es espontáneo y en vez de cargar, exige energía emocional a quienes participan-o directamente fallidos: en vez de producirse consonancia emocional y membresía grupal se solapan multitud de desencuentros, broncas y salidas dolorosas del colectivo. De este modo es que pudieron mantenerse cadenas de rituales de interacción

concepción de una comunidad obrera internacional o en el internacionalismo antifascista de la primera mitad del siglo veinte, así como en todas las formas de feminismo, ecologismo o decolonialismo internacionalista.

18. Un proceso que comienza en el momento que se desmontan las acampadas y culmina claramente en el invierno de 2011 por diversas razones, entre las que destacan, de manera predominante para lo que nos ocupa, la ruptura de la gobernanza de la cultura de la colaboración (ver RAzQUIN, 2014A: 67-68) y el establecimiento de la lucha sin cuartel por las mejores posiciones en el espacio simbólico desde las que establecer las visiones individuales como universales.

REDES.COM N ${ }^{\circ} 11 \mid 293$ 
referentes a la re-evocación de unas condiciones estructurales (de la experiencia a la que se encadenan) inexistentes en el momento de re-evocación. Paradójicamente, para quienes sí participaron en las actividades militantes del movimiento, las nuevas oportunidades de interacción, los nuevos rituales de interacción (donde podía haber sido recargada la energía emocional) no lograron despegar, resultando forzados y produciendo sentimientos de depresión o hastío.

En este sentido, se puede pensar en las celebraciones de los distintos aniversarios del movimiento donde, en general, la participación (que en ningún caso alcanzó las cifras de 2011) se ha orientado hacia actividades formativas, lúdicas y movilizaciones en clave de acción directa o manifestación y donde las distintas recreaciones de las acampadas ${ }^{19}$ y de las asambleas públicas y abiertas no han dejado de ser anecdóticas (a pesar de la contundencia con la que la policía ha tenido por costumbre impedir el acceso a diversas plazas por todo el Estado, algo que solía producir un efecto de afluencia masiva de simpatizantes). Estas actividades para los sucesivos aniversarios han tenido una adhesión de participantes menor y también menor efervescencia que en otras movilizaciones de plataformas hermanas como las de la PAH en la lucha por la Iniciativa Legislativa o en acciones directas no violentas, como parar desahucios u ocupar bancos. Desde el primer aniversario se hizo palpable - a pesar de las ganas y la dedicación de muchas personas implicadas en

19. Hablo de recreaciones porque quienes se mantenían en la organización del movimiento social trataron de reactivar la efervescencia volviendo a los lugares originarios, las plazas, tras una manifestación para desarrollar asambleas que se parecieran a lo que habían sido uno, dos o tres años atrás: coreando lemas míticos, haciendo aplausos mudos, etc. Pero en estas ocasiones la energía emocional no circulaba a raudales, había pocos carteles caseros y la mayoría de la gente, tras desembocar las movilizaciones en las plazas acababa marchándose. Muy pocas personas participan de las asambleas y además, en éstas, resulta imposible superar la brecha que separa a quienes se reincorporan con la referencia de las asambleas de las primeras semanas de acampada (donde se evitaban las discusiones políticas y se tendía a la celebración del encuentro) y a quienes han continuado participando en un espacio ya atravesado por la lucha de posiciones y referencias simbólicas e ideológicas de los márgenes izquierdos del campo político (pequeños partidos, sindicatos y organizaciones sociales) y tienen responsabilidades organizativas. Es decir, entre quienes participan en la asamblea para charlar un rato, hacer balance desde el plano afectivo o explicar su experiencia personal y quienes se mueven en la preocupación de recargar de participantes el proceso, que se tome alguna decisión militante importante (refortalecer las asambleas de barrio o recomponer algún grupo de trabajo, por ejemplo) o se explicite alguna postura política (convergencia o no con algunos sindicatos y partidos).

Bien parece que los aniversarios del 15M han tomado más el cuerpo de una conmemoración. 
la organización-la desvertebración entre la ya constituida organización del movimiento social (fuertemente formalizada) y la ciudadanía llamada a participar. En esta línea, quiero introducir otra reflexión para el análisis: si durante la acampada resultaba relativamente compleja la identificación de quienes pertenecían a la organización que iba conformándose ${ }^{20}$, el proceso de vaciado de las asambleas durante el verano favoreció que quienes siguieran acudiendo a las asambleas (generales o de coordinación, de grupos, etc.) fueran poco a poco tomando posiciones fundamentales en la organización del movimiento ${ }^{21}$-incluyendo a algunas personas que se habían integrado tras el final de la acampada - siendo, además, fácilmente reconocibles por el resto. Es muy importante reparar en esta división del trabajo militante y en la relación de dominación de las prácticas que implica: de un lado está la actividad militante que se da en el espacio público, la acción, y de otro el espacio de difusión y regocijo respecto a la misma, la reproducción. Pues aunque las actividades reproductivas son imprescindibles, no solo para la propia existencia del movimiento, sino para para mantener en circulación la energía emocional generada anteriormente en las interacciones cara a cara (en las movilizaciones y asambleas) y a pesar de que los y las militantes a tiempo completo también solían participar de la difusión de vídeos, fotografías, notas de prensa, carteles, llamamientos o desmentidos; a medida que avanza el proceso político, tendió a establecerse una separación entre quienes eran el motor y protagonistas de la acción militante en el espacio público no virtual y quienes operaban fundamentalmente en Internet relatando y difundiendo lo que las y los primeros realizaron, padecieron o sufrieron. Poco a poco estarán, por una parte, quienes aparecen en los vídeos (hablando en ruedas de prensa, siendo entrevistados y entrevistadas por periodistas, padeciendo la represión policial, etc.), que van acumulando en el transcurso grandes cantidades de capital simbólico - donde el inflacionismo del capital guerrero ${ }^{22}$ en

20. Personas que sabían dónde se guardaban las cosas quién podía tener el acta de la asamblea anterior, que sostenían la comunicación con otras acampadas, que sabían con certeza qué información era la correcta y cuál la desfasada, que conocían a casi todas las personas que tenían responsabilidades en la acampada, podían ayudar a solucionar un problema de electricidad, conexión a Internet, conseguir megáfonos, algún abogado, etc.

21 A su vez, estas personas van sintiendo la responsabilidad de seguir sosteniendo la dinámica militante tras el abandono del resto y el parón de nuevos ingresos.

22. Traslado el concepto utilizado por Thomas Sauvadet (2006) aunque no se ajuste perfectamente (lo construye ligado al análisis de la juventud en situación de exclusión social, por tanto, definido por prácticas relativas a ese espacio social), ya que puede descifrar muy bien disposiciones psicológicas y

REDES.COM N ${ }^{\circ} 11 \mid 295$ 
los montajes audiovisuales de las situaciones de resistencia o confrontación con la policía ${ }^{23}$ jugó un papel importantísimo-y, por otra, quienes "comparten" los vídeos, le dan al "me gusta" en Facebook o retwittean. Es decir, están primero quienes actúan y después su alteridad, limitada a felicitarse o empatizar con las acciones de quienes actuaron. Así, aún cuando el medio virtual operará como engranaje más que fundamental para mantener la cohesión grupal y activar cadenas de rituales de interacción a distancia; es importante reparar que lo hace, en términos de Simone De Beauvoir (2008 [1949]: 478), como el espacio militante para el "éxito pasivo".

\section{INTERNET COMO ESPACIO PARA LOS DISCURSOS SUBALTERNOS EN EL ESPACIO ASAMBLEARIO: EL ON-LINE COMO REFUGIO DEL OFF-LINE}

Uno de los efectos más significativos del cierre democrático que sufrió la asamblea del $15 \mathrm{M}$ estudiada fueron las salidas masivas y fallidos reenganches que se sucedieron del otoño de 2011 en adelante. Es importante señalar, para situar lo que sigue, que a diferencia de lo que sucedió en otras ciudades, en el caso estudiado la primera asamblea, aquella que nació al calor del campamento en una plaza del centro de la ciudad, tomó el cuerpo de "asamblea general", máximo órgano regidor del 15M local (aunque incluía algunos matices: soberanía de las asambleas barriales y sus grupos de trabajo respecto a su circunscripción). Este proceso se dio gracias al empuje de una parte de los y las participantes: quienes no participaban también en la asamblea de su

articulaciones prácticas cercanas. Me interesa, fundamentalmente, apuntar a la centralidad de la virilidad y la ideología machista que sustenta este tipo de capital y al potencial de este concepto para desentrañar las relaciones de dominación y de diferenciación basadas en la fuerza física y en el grupo numeroso.

23. Muchos de los montajes audiovisuales que difundieron, por ejemplo, el desalojo de la Puerta del Sol o el de Plaza Cataluña (donde la violencia policial fue brutalmente desmedida) mostraban un fuerte regocijo y actitud morbosa en las escenas más violentas. Por ejemplo, se ralentizaba el ritmo, se detenían imágenes sangrientas y de golpes, o se eliminaba el audio original para sustituirlo por melodías de películas épicas de la industria hollywoodense: Braveheart fue la predilecta.

Este tipo de producciones audiovisuales - que se mueven entre los movilization videos y los witness videos de Askanius (2013) - serán muy típicas de las células de DRY y se compartieron de manera frenética. La épica de todo el relato que presentaban este tipo de producciones videoactivistas aumentaba la ebullición de la emoción y eran preferidos (los más compartidos) a otro tipo de registros no editados. Siendo escaso su valor documental, lo que indica su masiva recepción es, precisamente, la potencia que engendran en tanto que activadores de interacciones a distancia que hacen circular gran cantidad de energía emocional. 
barrio y quienes pretendían centralizar el control político del proceso en la misma para asegurarle espacio de posibilidad a su facción política.

En el mes de mayo de 2011, la cifra máxima de participación se situaban en más de 3.000 personas y se registró el 22 de mayo, día de jornada de reflexión. La decisión de la Junta Electoral Central de prohibir las acampadas, junto con la posible actuación de la policía nacional (dependiente de las decisiones que tomaran las distintas Subdelegaciones del Gobierno en cada ciudad), copó las noticias relacionadas con el proceso electoral. Por ello, a la hora de analizar las cifras, se debe tener cautela con el fuerte efecto de mediatización que animó la participación. Ahora bien, las 1.000 personas que se reunieron el segundo día de acampada, el 19 de mayo - una cifra que marcará ya la tendencia de participación hasta los últimos días de acampada - fueron movilizadas por redes informales, medios alternativos y, fundamentalmente, redes sociales virtuales y con co-presencia corporal; ordinarias y militantes. De hecho, hasta el tercer o cuarto día el fenómeno no era mediático, ni siquiera merecía notas breves en la prensa local.

Pues bien, cuando se desmontó la acampada, la participación en la asamblea general, que superaba habitualmente, como decía, las 1.000 personas y las 2.000 los fines de semana, cayó a una media de 350 (y haciéndose una única asamblea el día sábado). A partir de octubre no se remontó el número, salvo que hubiera que tomar alguna decisión que incumbiera de manera importante a los barrios (solo seguían existiendo ya tres de las seis asambleas barriales que se constituyeron en junio, pero en ellas se concentró buena parte de las y los participantes). Aumentó hasta 250 en la jornada electoral de noviembre (en otras actividades de la misma jornada, como tratar de entrar a la plaza acordonada por la policía, participaron alrededor de 400 personas) y en las jornadas del primer aniversario, en mayo de 2012, hasta cerca de 300 personas en la asamblea más multitudinaria. Se lograron reunir unas 80 personas cuando se iba a ratificar el modelo de coordinación y de circuito de toma de decisiones, o cuando hubo algún orden del día cargado de decisiones que involucraban a varios grupos de trabajo (las personas de esos grupos acudían a la asamblea general haciendo subir el número de participantes); pero fueron frecuentes y habituales asambleas con no más de 20 personas.

En algunos casos, la salida de la asamblea general se armonizó con la participación en otros espacios militantes, como los grupos de trabajo o las asambleas barriales y de pueblos que se crearon rápidamente desde el final de la segunda semana de acampada. En la mayoría, la salida de los espacios organizativos, deliberativos y de toma de decisiones fue total. 
En mitad del proceso de desafección que animó muchísimas de las salidas y que respondía a un triple cierre - a) ideológico, b) de cultura participativa, sobre el repliegue de la idea de la pluralidad de orígenes sociopolíticos y de posiciones como motor de la riqueza del consenso y c) de la actividad militante, cierre para la participación profana e imposición de ritmos militantes imposibles para vidas con responsabilidades reproductivas o con largas jornadas laborales) - , el menú de discursos posibles mermó estrepitosamente e Internet se presentó como un espacio privilegiado para la exposición y desarrollo de los discursos subalternos; de aquello que en las asambleas con co-presencia corporal se vivía y entendía imposible de decir.

Me detendré un instante en el desarrollo de este planteamiento ayudándome de la ya clásica trilogía exit, voice and loyalty; aunque bien es cierto que no comparto la propuesta explicativa en la que Hirschman (1970) la moviliza, pues, entiendo, se apoya una visión idealizada de la lógica del mercado de bienes materiales ${ }^{24} \mathrm{y}$ salta de este análisis al del comportamiento ciudadano respecto a la desafección ante el cierre democrático de un Estado o al mal funcionamiento de los servicios públicos a partir de una homología vertebrada sobre la acción racional ${ }^{25}$. Sin embargo, al mismo tiempo, el esquema básico sigue siendo útil, pudiéndose además rescatar para ser activado en el marco de otra teoría de la acción social (la bourdisiana en este caso) y aplicarlo al caso de una movilización popular o un movimiento social.

En 1970 Albert Hirschman proponía la trilogía "salida, voz y lealtad" como posibilidades prácticas desde las que analizar la desafección respecto de una organización por un mal funcionamiento o por una desvirtuación de sus características originales. En el esquema básico de Hisrchman la salida supone que la clientela deja de comprar y la ciudadanía se va, deja de participar en el espacio cívico. La voz supone que quienes se oponen a las decisiones estatales o se encuentran insatisfechos con el producto reclaman; lo que es lo mismo: activan repertorios de acción contestataria. Y, por último, la lealtad supone quedarse con el producto, seguir participando (SANTISO, 2000: 102).

La argumentación sería más o menos la siguiente. Ante la desafección existirían dos opciones. La primera (salida) consiste en que los y las consumidoras dejan de comprar el producto o que ciertos participantes dejan la organización; el resultado es que el número de miembros baja o que el producto deja

\footnotetext{
24. Al no renunciar al supuesto de que la ley de la oferta y la demanda es el motor de dicho mercado y su eje principal la actitud crítica de los consumidores.

25 En este caso, la propuesta alternativa en el uso de la teorización sería semejante como para el caso de Collins: el sentido práctico.
} 
de venderse. Así, la organización, o la empresa, realizará cambios para volver a conquistar a clientes, afiliados o ciudadanos que se han marchado de un país, si se piensa en un Estado ${ }^{26}$. La segunda (voz) implica que consumidores o ciudadanos expresan directamente sus opiniones iniciando movilizaciones contestatarias (HIRschman, 1970: 4, 15-20). Según el esquema de Hirschman, si bien la opción de salida en el seno del mercado de bienes materiales resulta satisfactoria, pues las empresas dependen de vender sus productos ${ }^{27}$, respecto a la participación política deviene fatal. La voz

(...) implica la articulación de las propias opiniones críticas en lugar del "voto secreto" en el anonimato de un supermercado y, por último, es directo y franco. La voz es la acción política por excelencia (ов. сіт.: 16).

Para proseguir con el desarrollo argumental, resultará interesante reparar en las condiciones sociales necesarias para poder articular la protesta, la voz.

Hirschman señala que solo en configuraciones donde se dan dinámicas de lealtad elevada (cabría añadir, y una sanción importante de la disidencia por considerarla desleal) la voz implica más efectos negativos que la salida del grupo: “(...) la voz puede resultar más costosa que la salida cuando ésta última supone desprenderse de la esencia de su propia identidad" (santiso, 2000: 102). Pero para poder explorar un poco más en las condiciones necesarias para que la voz pueda darse, quisiera incorporar el planteamiento foucaultiano analizado por Moreno Pestaña (2011B) junto con una aportación fundamental que hace el autor a la argumentación de Foucault. Para el filósofo francés, la parresia es la palabra libre, la palabra franca. Ésta no es fácil de emitir porque requiere un riesgo y, además, no se deriva automáticamente de las condiciones institucionales de su ejercicio.

26. Esto no siempre sucede así; bien por incapacidad o bien porque, en la generalidad de las situaciones si nos referimos al campo político, la intención lejos de ser integrar a todo el mundo (como clientela con una empresa) es precisamente someter o expulsar a la disidencia. Puede pensarse en los casos extremos de las dictaduras militares o las peleas descarnadas en ciertos espacios de concentración de poder político y económico.

27. Aunque como él mismo señala analizando el caso del ferrocarril en Nigeria, la "salida" no tuvo su habitual efecto porque la pérdida de ingresos no era una cuestión de suma gravedad para la administración y la "voz" no funcionó. Finalmente, la mayoría de usuarios abandonó el ferrocarril por los autobuses. 
No hay manera de despersonalizar la parresia, ésta supone que la persona diga lo que dice con convicción, pactando pues consigo mismo y con la realidad (GS, 6o) pues una condición de la parresia es la coherencia entre qué se dice, qué se experimenta y qué se hace (MORENO PESTAÑA, 2011B: 111).

Respecto a la política, las condiciones necesarias para hablar libremente serían cuatro: (a.) la existencia de una asamblea democrática; (b.) el desigual prestigio de quien habla (pues Foucault entiende la desigualdad de múltiples prestigios como clave de la libertad ya que solo los tiranos igualan la lucha entre los prestigios al suprimirlos e imponer el suyo propio); (c.) que la opinión sea verdadera - donde verdadera significa racional y que quien la emite cree en ella firmemente-. Y, por último, (d.) que se asuma el riesgo que supone emitirla (ов. сіт.: 112-113). Habría una quinta, añadida por Moreno Pestaña: (e.) las condiciones materiales y sociales para el acceso a la palabra ${ }^{28}$.

Pues bien, si pensamos la voz de Hirschman incluyendo el análisis de las condiciones de la parresia, pues la voz para ser en plenitud necesita unas condiciones de producción en libertad, podemos volver sobre el análisis de las asambleas del invierno de 2011 en adelante y comenzar a desgranar qué condiciones debían estar dándose ${ }^{29}$ para que mayoritariamente las y los militantes que no encontraron armonía entre sus intereses, posiciones o aspiraciones políticas optaran por la opción de "salida", renunciando a la acción política por excelencia según Hirschman: expresar el desacuerdo.

En algunos casos (militantes con mucha implicación en el proceso desde el comienzo de las acampadas) lo hicieron y no consiguieron sino rechazo; saliendo, finalmente, del espacio asambleario. En algunas ocasiones hubo quienes quisieron manifestar públicamente su salida, optando por hacerlo en la página oficial de Facebook de la acampada en cuestión.

A continuación expondré una transcripción del mensaje de una militante muy implicada en el proceso. Lo escribió en el espacio de comunicaciones públicas, el "muro". Expongo de manera íntegra el mensaje y la secuencia de comentarios y adhesiones ("me gusta") que recibe de otros y otras participantes. Éste es un abandono de la participación en la asamblea general muy

28. Esta última condición apuntada por Moreno Pestaña se concreta en el caso estudiado, por ejemplo, sobre el capital cultural, social, corporal, militante, emocional... y, también, sobre la disponibilidad; sobre el tiempo libre que se tiene para estar, participar y tomar partido en las decisiones y en las acciones. 29. Algo para lo que no hay espacio en este artículo. Pueden verse al respecto otros trabajos donde abordo en profundidad esta cuestión en Razquin, 2013, 2014a y 2014b.. 
tardío respecto al enorme proceso de salida masiva. La explicación reside en la gran adhesión de esta participante al proceso (que implicaba una buena red de amistades al interior) y a que logró reacomodar con estabilidad su participación, concentrándose en las tareas reproductivas de la vida del movimiento (venta de camisetas, tesorería, difusión de actas y llamamientos o convocatorias en Internet y en la calle, sostenimiento del equipo de moderación etc.), participando en una asamblea del $15 \mathrm{M}$ en un pueblo cercano a la ciudad en cuestión y colaborando con Stop-desahucios y Yayoflautas. Las intervenciones de esta participante en las asambleas de octubre en adelante eran fuertemente sancionadas por dos elementos que con el paso del tiempo se consolidaron como contrarios a las posiciones hegemónicas: (a.) el cuestionamiento de ciertas prácticas incorporadas en la acción militante por considerarlas violentas - o dudar de que pudieran serlo- y (b.) apuesta por mantener la convergencia con Democracia Real Ya, como expresión de la lucha por la pluralidad.

Finalmente a finales de julio de 2012 (esto es, casi un año después de la salida masiva de participantes) Marina dejó el siguiente mensaje en el muro del Facebook oficial del movimiento a nivel local:

Marina: «Definitivamente abandono este grupo. Para los que se pregunten por qué [les diré:] porque estoy hasta los ovarios de la actitud dictatorial y fascista de los sheriffs de la plaza y yo estoy luchando por una democracia real.

P.D.: Definición de dictatorial: dicho de un poder, de una facultad, etc.: absolutos, arbitrarios, no sujetos a las leyes. Definición de fascista: perteneciente o relativo al fascismo/partidario de esta doctrina o movimiento social/ excesivamente autoritario.»

[Nueve personas inscritas en el grupo virtual señalan "me gusta" al comentario ${ }^{30}$.]

30. Resulta imposible cuantificar lo representativo respecto del grupo general que suponen estos nueve "me gusta". En ese momento 3.015 personas están inscritas en el grupo, sin embargo resulta igualmente imposible dimensionar qué significa estar inscrito, qué significa el silencio respecto de los foros (a cada nueva entrada aparece un mensaje de actualización en la página principal de cada usuario) o cuántas personas siguen silenciosamente sin intervenir (una suerte de voyerismo militante) los debates, opiniones o argumentaciones de los y las demás. Lo que sí manifiesta es que en el momento de este mensaje, el verano de 2012, el número de participantes activos en los espacios militantes virtuales era ínfimo en proporción al número total de personas inscritas (fundamentalmente en las dos primeras semanas de acampada).

REDES.COM N $\mathrm{N}^{\circ} 11 \mid 301$ 
[En un par de minutos.]

Un participante: «Brindo por el camino hacia la libertad de expresión.»

[Cuatro personas señalan "me gusta" al comentario. Tres de ellas lo habían hecho también sobre el de Marina.]

Otra participante: :(

Otra participante: «Joder, es una pena $\mathrm{k}$ gnt $\mathrm{cm}$ Marina que trabaja duro en st grupo se vaya por los que desde un principio han hecho que esto se vaya quedando sin gente y se desvirtúe el movimiento. Montaros un puto partido político o seguir $\mathrm{n} \mathrm{k} \mathrm{k}$ steis y dejar d dar x culo ${ }^{31}$.»

[Transcurridas dos horas.]

Marina: «Por cierto, para todos los que se preguntan por qué cada vez hay menos gente en la asamblea y en los grupos de trabajo, he aquí un gran motivo (que no digo que sea el único, ojo).»

[Un minuto más tarde.]

Marina: «Y lo que más me apena es dejar atrás a grandes compañeros, a los que ya se fueron (por este y/u otros motivos) y a los que están. Un fuerte abrazo a todos, nos vemos en otros sitios.»

[Cuatro personas clican "me gusta". Tres que lo habían hecho ya en la entrada principal y una nueva.]

Otra participante: «Una vez leí que en la antigua Grecia el sistema asambleario fue lo que hundió a su sistema político ${ }^{32}$. Fuerza Marina, que hay muchos por quienes hacer.»

31. Mantengo la escritura en versión original para mostrar la forma en la que se interviene, probablemente desde un teléfono móvil (donde resulta tedioso teclear), bajo la doctrina de la inmediatez. Esta intervención se sucede a las dos anteriores y éstas a la original en apenas unos minutos.

32. Sin pretender comentar cada entrada - varias merecerían explicaciones y matizaciones muy extensas, sobre todo los juicios de valor, los prejuicios y las pretensiones de vincular la desafección exclusivamente a un mal hacer de los rivales políticos-, no quisiera dejar pasar la oportunidad de plantear que, más allá de lo certera o no que resulte esta afirmación, es importante reparar en que para quienes el 15M había sido su única experiencia asamblearia pueden, como en este caso, manifestar una desafección hacia el asamblearismo (o reafirmar prejuicios), cuando en el fondo, lo que estaba sucediendo es que las condiciones necesarias para su desarrollo se habían roto: se había producido un cierre democrático acompañado de un deterioro de las herramientas institucionalizadas para el desarrollo de dinámicas horizontales: rotación de los turnos de palabra, respeto a las posiciones minoritarias, el consenso como finalidad, etc. 
[Tres participantes que también lo hicieron en la primera entrada, señalan "me gusta".]

Otra participante: "Como tú veas Marina, aunque lo de "la actitud fascista y dictatorial de los sheriff de la plaza” además de exagerado me parece ofensivo. No voy a cuestionar si quieres dejar o no el movimiento ni tampoco los motivos, pero sí pido un poco de respeto para los que semana tras semana nos reunimos en la plaza para luchar por un sistema mejor.»

[Dos participantes, que no lo habían hecho antes en todo el hilo, señalan "me gusta”.]

Otro participante: «El movimiento o se renueva o muere, partido político ya.»

Otro participante: «Yo pasé del 15M desde que vi que ciertos grupos de DRY fueron tomados por falangistas o de UPyD, y que por otra parte asambleas como las de [la ciudad en cuestión] fueron lideradas (sin permitir crítica o alternativas) por anarquistas radicales que no entienden otra cosa que no sea violencia y radicalismo. Veréis, yo soy comunista, voto a IU y soy supercrítico dentro del partido para que no se desvirtúen como pasa ahora en la Junta. Sin embargo, me uno a compañeros de otras ideologías, pues lo primero ¿qué es? Que no se pierda la educación, que no vayamos hacia atrás. Quienes abogan por "ruptura o nada" hacen que perdamos muchísimos adeptos y ya nosotros mismos demos el movimiento por muerto. Y ya que estamos, más que partido, bloque cívico similar al que propone Anguita, donde quepa un 60 o 70\% de la ciudadanía.»

[Dos participantes, que no lo habían hecho hasta el momento, indican "me gusta".]

Otro participante: «¿En serio? ¿Las asambleas del 15M en [la ciudad en cuestión] fueron tomadas por anarquistas?»

[Dos participantes, uno de ellos ya lo había hecho en el comentario principal, señalan "me gusta".]

Otro participante: [Apela al participante de hace dos comentarios] «Anguita propone que la izquierda se una en un Frente Cívico sin descalificaciones ni soberbias. Naturalmente, su intento va a fracasar. Todas las izquierdas son estupendas, se dicen ellas mismas que son las únicas auténticas. Es más difícil que las izquierdas se unan que un camello pase por el ojo de una aguja. Aunque sean mayoría, como afirma Julio Anguita. 
Mayoría culpable, añado yo. Son el líquido corrosivo que definitivamente liquida España y su rehabilitación. La catástrofe de Rubalcaba, el primitivismo de Cayo Lara, los cantos de sirena varada de los ecologistas, Izquierdas Anticapitalistas minúsculas, marxistas enrocados, abstencionistas, anarquistas y ácratas magos de la nada y el simple inconformismo. Yo tengo el carné del PC del tiempo de Carrillo y ya me he desengañado, mientras hablemos de izquierdas y derechas solo encontraremos rechazo y enfrentamientos.

A ti Marina, no te conozco personalmente pero te leído en este foro y me pareces una persona muy válida, por eso quiero darte un consejo, si te vas que sea porque te has cansado y no porque cuatro imbéciles te echen, porque al final esos cuatro se van a salir con la suya y se van a quedar solos. Salud.»

[Cinco participantes señalan "me gusta". Cuatro de ellos lo harían anteriormente y una de ellas es la participante que confronta a Marina por el tono descalificador de sus palabras.]

Otro participante: «Marina, me apena enormemente que personas como tú, que trabajan con entusiasmo abandonen el movimiento (aunque no el activismo), pero entiendo perfectamente tus razones. Yo también he ido apartándome de las asambleas por los mismos motivos que tú. Sin embargo sigo trabajando activamente en iniciativas de participación ciudadana en colaboración con el ayuntamiento de [un pueblo en la periferia de la ciudad en cuestión gobernado por IU]. Quiero decir con esto que, aunque ya no participes en las asambleas, espero que encuentres otras vías de participación porque tu aportación es siempre necesaria. Muchos besos y mucha suerte. Nos veremos pronto.» Otro participante: «Ánimo Marina.» [Un día después.]

Otro participante: «Marina, tú eres lo suficientemente inteligente para saber dónde tienes que estar, también sabes que en todos los grupos hay personas muy válidas, por lo que a lo mejor no sea la cuestión abandonar grupos sino rehuir posturas con las que no estás conforme, nos conocemos hace más de un año y siempre he estado a tu lado, sigo estándolo.»

[Un participante que ya lo haría en la entrada principal señala "me gusta".] 
Otra participante: «Tranquila Marina. La lucha no se acaba, hay miles de sitios donde se puede seguir trabajando. ¡Eres una trabajadora nata! Y si los "dictadores” no lo ven ya se darán cuenta con el tiempo... Es absurdo "espantar" a personas como tú con lo que curra... ¡mucho ánimo! Y ¡ya sabes! Aquí tienes a un grupo de personas dispuestas a ¡seguir codo con codo contigo en la lucha!»

[Dos participantes señalan "me gusta". Ya lo hicieron al comienzo.] Otro participante: «Ole, ole y ole esa Marina... Hace mucho que me fui de la plaza por motivos personales, pero tengo muy claro que si tú denuncias esa actitud por parte de xx no me extraña nada.»

[Dos días después.]

El mismo participante en otra entrada: «Ánimo Marina porque sé que vas a seguir luchando, mejor sola que mal acompañada... Te mando un beso muy grande.»

Otro participante: «Marina, lo siento mucho. Sabes que te aprecio y que estoy seguro de que tienes tus argumentos, espero que nos sigamos encontrando porque el 15M ha sido solo el principio y hay muchos frentes abiertos. $\mathrm{Y}$ a muchas de las personas que han hecho comentarios aquí arriba tengo que decirles una cosa: no tenéis ni puta idea. Los que dicen que las asambleas del 15M de [la ciudad en cuestión] fueron tomadas por anarquistas no merecen ni mi respeto. Es muy triste que se despida a una compañera como tú despotricando de las asambleas. Lo único malo que éstas han hecho (y yo me incluyo plenamente) es no haber sabido parar las faltas de respeto personales que se han dado dentro de ellas. Espero que tod@s aprendamos.»

[Cuatro participantes dan al "me gusta", una de ellas la participante que le llama la atención por faltar al respeto.]

Otro participante: «Ánimo Marina, afortunadamente hay muchas vías para continuar, ya llevas un largo camino recorrido y eres una luchadora nata. Por suerte antes del famoso 15M del 2011 y después claro, se crearon múltiples vías distintas a lo que estábamos acostumbrados por entonces para cambiar las cosas. Aun así, si ves que éstas no llegan a ningún sitio, habrá que hacer caminos nuevos. Siempre es bueno hacer un alto en el camino para ver cómo se está; observar el horizonte al que 
quieres llegar y estudiar qué posibles caminos te pueden llevar a él, aparte del que se lleva.»

Otro participante [en referencia al emisor del antepenúltimo comentario.]: «Estoy completamente de acuerdo contigo.»

En el hilo de conversación virtual podemos ver, desde un plano más externo, los límites discursivos y el corsé simplificador de los códigos de expresión que permite la lengua escrita, donde la orientación del discurso - sobre todo a nivel emocional- se representan con alto grado de ambigüedad, a pesar de los emoticonos y signos de exclamación o interrogación (por ejemplo, la ironía en la undécima intervención: "¿En serio? ¿Las asambleas del $15 \mathrm{M}$ en [la ciudad en cuestión] fueron tomadas por anarquistas?"). Además, la interacción discursiva puede darse casi en tiempo real y con todos los agentes implicados participando o, por el contrario, puede darse en diferido - respecto de la intervención que activa la respuesta-e, incluso, con la agente iniciadora fuera de la conversación: a partir de un momento de la conversación Marina deja de interactuar. Al menos, deja de plasmar una huella escrita. Y tras esta falta de huella escrita en el hilo de la conversación pública, bien podría haber interacción en privado: una respuesta de Marina mediante mensaje privado a alguna de las opiniones escritas en el hilo de conversación pública; podría haber recepción sin respuesta: Marina lee las intervenciones escritas pero no las responde. $\mathrm{O}$, incluso, podría no haber recepción: Marina cancela su suscripción al grupo virtual - al menos un mes después de esta intervención no aparecía ya inscrita - y deja de recibir las notificaciones respecto de la conversación iniciada por ella misma.

Desde un plano de análisis más ligado al proceso particular y al contenido y orientación de las intervenciones, esta conversación condensa la búsqueda de espacios marginales, paraasamblearios, y protegidos, que permiten una distancia protectora para desahogarse. También para despacharse abiertamente e incorporar un tono duro o, quizá, malicioso (aunque se siguen manteniendo eufemismos, expresiones en clave y sobreentendidos) respecto de un tema lo suficientemente conflictivo como para no hacerlo en el ágora de la plaza, y vivido como algo lo suficientemente importante y tocante con lo común como para buscar un espacio público ${ }^{33}$. Pero un espacio que, aunque público, se presenta frecuentemente subsidiario de las dinámicas asamblea-

33 Nadie, nunca, comunicó la decisión de retirar su participación en la asamblea general, que sería, de alguna manera, la forma "reglamentaria" en tanto es el espacio oficial» por antonomasia para las comunicaciones 
rias en las plazas (después en los locales): el efecto que puede producirse a través de él, salvo que se acumule mucho prestigio asambleario al mismo tiempo, no resulta sino atenuado y marginal.

Como he mostrado, desarrollar una aproximación etnográfica de los usos sociales de los dispositivos que operan en Internet (reintegrando la dimensión on-line y off-line en el marco general de estrategias militantes de un movimiento social) permite enriquecer las descripciones y conceptualizaciones sobre su incorporación en el repertorio militante de los movimientos sociales. Además, implica resituar empíricamente estos usos activistas permitiendo desvelar: (a) el papel que ocupan los dispositivos virtuales en el sostenimiento de cadenas de rituales de interacción a distancia, así como el efecto de "éxito pasivo" que también sostienen; y (b) que frecuentemente operan como refugio para posiciones y discursos que no tienen cabida en los espacios militantes, que son el motor del movimiento: las asambleas, grupos de trabajo, acampadas y resto de movilizaciones con co-presencia corporal.

\section{BIBLIOGRAFía}

ANTOLÍN, Verónica (2014). En los orígenes del Movimiento Indignado en España. Estado del Malestar: de Facebook a Sol, un estudio de caso. Jornadas Tres años de indignación, Madrid: Contested Cities Nodo UAM-Madrid, Facultad de Ciencias Políticas y Sociología de la UNED, Federación Española de Sociología, Universidad de Salamanca, Universitat de Vic, Fundación Betiko y Comunaria.

ASKANIUS, Tina (2013). Online Video Activism and Political Mash-up Genres. JOMEC Journal Journalism, Media and Cultural Studies, número 4.

Dirección: lup.lub.lu.se/record/4180637/file/4180639.pdf (Última visita: 27 de agosto de 2015).

BEAUVOIR (DE), Simone (2008 [1949]). El segundo sexo, Madrid: Cátedra.

BOLTANSKI, Luc (1990). L'Amour et la Justice comme competences, París: Éditions Métailié.

BOURDIEU, Pierre (1999 [1988]). La distinción. Criterios y bases sociales del gusto, Madrid: Taurus.

BOURDIEU, Pierre (2000). Propos sur le Champ Politique, Lyon: Presses Universitaires de Lyon.

CANDÓN MENA, José Ignacio (2011). Internet en movimiento: nuevos movimientos sociales y nuevos medios en la sociedad de la información [Tesis 
Doctoral], Madrid: Facultad de Ciencias de la Información, Universidad Complutense de Madrid.

CANDÓN MENA, José Ignacio (2012). Ciudadanía en la Red: poder y contrapoder en los medios de comunicación. Estudios sobre el mensaje periodístico, número 18 , volumen 2, pp. 679-687.

CASTELLS, Manuel (2012). Redes de indignación y esperanza: los movimientos sociales en la era de Internet, Madrid: Alianza Editorial.

COLLINS, Randall (2009). Cadenas de rituales de interacción, Madrid: Anthropos.

COULDRY, Nick (2004). Theorising media as practice. Social Semiotics, número 14, volumen 2, pp. 115-132.

DÍAZ DE RADA, Ángel (2008). La mediación computacional de la comunicación y la lógica de la investigación etnográfica: algunos motivos de reflexión en ARDÉVOL PIERA, Elisenda; ESTALELLA, Adolfo y DOMÍNGUEZ FIGAREDO, Daniel (Coords.)., La mediación tecnológica en la práctica etnográfica, Donostia: Ankulegi Antropologia Elkartea.

DÍAZ DE RADA, Ángel (2010). La lógica de la investigación etnográfica y la mediación computacional de la comunicación. Viejos problemas con un nuevo énfasis. Revista Chilena de Antropología Visual, número 15, Santiago: Centro de Estudios en Antropología Visual.

GALINDO CÁCERES, Jesús (1997): Comunidad virtual y cibercultura. El caso del EZLN en México, en SIERRA CABALLERO, Francisco (Coord.)., Comunicación e insurgencia. La información y la propaganda en la guerra de Chiapas, Hondarribia: Hiru.

GARRIDO, María; BARON, Fernando y ABOKHODAIR, Norah (2013). The movements of social media. The appropriations of Facebook in the strategy of the April 6th Youth Movement in Egypt. XI Congreso Español de Sociología Crisis y cambio: propuestas desde la sociología, Madrid: Federación Española de Sociología.

GUTIÉRREZ, Alicia B. (2002). Las prácticas sociales. Una introducción a Pierre Bourdieu, Madrid: Tierradenadie ediciones.

HARD, Michael y NEGRI, Antonio (2012). Declaration.

Dirección: https://antonionegriinenglish.files.wordpress. com/2012/05/93152857-hardt-negri-declaration-2012.pdf (Última consulta: 13 de julio de 2015).

HIRSCHMAN, Albert. O. (1970). Exit, Voice and Loyalty: Responses to Decline in Firms, Organizations and States, Cambridge (Massachusetts): Harvard University Press.

LAWRENCE, Jeffrey (2013). Las raíces internacionales del 99\% y la ’política 
de cualquiera'. IC-Revista Científica de Información y Comunicación, número 10, pp. $53-72$.

MATEOS, Concha y RAJAS, Mario (2014). Videoactivismo: conceptos y rasgos, en VV.AA., Videoactivismo. Acción política cámara en mano, La Laguna: Sociedad Latina de Comunicación Social.

MATHIEU, Lilian (2004). Comment lutter? Sociologie et mouvements sociaux, Paris: Textuel.

MORENO PESTAÑA, José Luis (2011a). Pensar la palabra libre con Michel Foucault: una etnografía de las asambleas del 15-M. Pasajes: revista de pensamiento contemporáneo, número 36, pp. 89-99.

MORENO PESTAÑA, José Luis (2011b). Foucault y la política, Madrid: Tierradenadie Ediciones.

POUPEAU, Franck (2007). Dominación y Movilizaciones. Estudios sociológicos sobre el capital militante y el capital escolar, Córdoba: Ferreyra Editor.

RAZQUIN, Adriana (2013). Aperturas y cierres en el movimiento 15M: ingresos y salidas del espacio asambleario. Un estudio de caso. XI Congreso Español de Sociología Crisis y cambio: propuestas desde la sociología, Madrid: Federación Española de Sociología.

RAZQUIN, Adriana (2014a). En la plaza se habla. Algunas claves para analizar la toma de la palabra en el $15 \mathrm{M}$. Ímago Crítica. Revista de Antropología $y$ Comunicación, número 4, pp. 57-76.

RAZQUIN, Adriana (2014b). Tomar la palabra en el 15M: condiciones sociales de acceso a la participación en la asamblea. Un estudio de caso [Tesis Doctoral], Cádiz: Facultad de Filosofía y Letras, Universidad de Cádiz.

RAZQUIN, Adriana (2015). Desbordamientos y viaje hacia la izquierda. Prehistoria del movimiento 15M: de Nolesvotes a Democracia Real Ya. Revista Internacional de Filosofía Daimon, número 64, pp. 51-70.

REVILLA BLANCO, Marisa y HOVÁNYI, Réka (2013). La 'primavera árabe' y las revoluciones en Oriente Medio y Norte de África: episodios, acontecimientos y dinámicas. XI Congreso Español de Sociología Crisis y cambio: propuestas desde la sociología, Madrid: Federación Española de Sociología.

ROMANOS, Eduardo (2015). De Tahrir a Wall Street por Puerta del Sol: La difusión transnacional de los movimientos sociales en perspectiva comparada, Revista Española de Investigaciones Sociológicas (en prensa).

SALINAS SALAZAR, Alejandro (2015). La ola internacional de protestas 20082013: notas para una reflexión comparada, número 9, pp. a0903.

SANTISO, Javier (2000). La mirada de Hirschman sobre el desarrollo o el arte de los traspasos y las autosubversiones. Revista de la CEPAL, número 7o, pp. 91-106. 
SAUVADET, Thomas (2006). Le capital guerrier, París: Armand Colin.

SNOW, David A.; ROCHFORD, Burke; WORDEN, Steven K. y BENFORD, Robert D. (1986). Frame alignment processes, micromobilization and movement participation. American Sociological Review, número 51, volumen 4, pp. 464-481.

TILLY, Charles (2005). Los movimientos sociales entran en el siglo veintiuno. Política y Sociedad, número 42, volumen 2, pp. 11-35.

TRERÉ, Emiliano y BARRANQUERO, Alejandro (2013). De mitos sublimes digitales: movimientos sociales y tecnologías de la comunicación desde una perspectiva histórica. Redes.com Revista de Estudios para el Desarrollo Social de la Comunicación, número 8, pp. 27-47. 